\title{
IDENTIFYING PLANT COMMUNITIES RESISTANT TO CONIFER ESTABLISHMENT ALONG UTILITY RIGHTS- OF-WAY IN WASHINGTON AND OREGON, U.S.
}

\author{
by Jeff Shatford, David Hibbs, and Logan Norris
}

\begin{abstract}
A program to assess the utility of stable, lowgrowing plant communities in suppressing conifer seedling establishment along electrical rights-of-way was initiated in the states of Washington and Oregon, U.S., in 1999. The percentage of cover of all woody species and density of tree stems was described at three sites by sampling 1,376 plots, each $2 \times 2 \mathrm{~m}$. We asked if tree seedlings, principally Douglasfir (Pseudotsuga menziesii), were distributed randomly among community types defined by growth form and percentage of cover. Douglas-fir seedlings were not randomly distributed and occurred less frequently within communities already occupied by dense vegetation. This included some, but not all, low-growing communities-e.g., areas of dense grass or shrub communities of moderate to high cover. Douglas-fir seedlings were infrequent within patches dominated by trees and tall shrubs, but these do not fit the low-growing requirement of the program. Of particular concern to vegetation managers was the large number of Douglas-fir seedlings that regrew from an uncut lateral branch.
\end{abstract}

Key Words. Right-of-way; vegetation control; stable, low-growing plant community.

The safe and reliable operation of a high-voltage electrical power grid requires the removal of vegetation within transmission rights-of-way (ROW). Continued removal of vegetation along an electrical transmission ROW through a forested landscape leads to a condition that has been called an arrested stage of succession (Hill et al. 1995). This stage is not characterized by any single community type or species composition; rather, a range of conditions exists. Part of the goal of integrated vegetation management in this setting is to reduce the costs and inputs in removing unwanted vegetation. To this end, some vegetation types might be preferable to others; namely, those that are lowgrowing and that compete well with taller species (trees).

Utilities operating in the rugged and heavily forested U.S Pacific Northwest have developed an interest in encouraging stable, low-growing plant communities as an alternative to traditional treatments (Bonneville Power Administration 2000). The theory and practice of this method have developed primarily in the context of forest and old-field commu- nities in eastern North America (Hill et al. 1995). Unwanted vegetation is removed in a manner that allows shorter plants (grasses, forbs, ferns, and shrubs) to fill in the gaps. The principle supposes that low-growing plants in sufficient density will reduce the establishment and growth of undesirable trees and tall shrubs. Establishing stable, low-growing communities may reduce the frequency, amount, and cost of manual and chemical treatments over the long term. A stable, low-growing community rich in flowering forbs and shrubs may also improve wildlife habitat (Bramble et al. 1992) and control invasive weeds effectively.

Vegetation within a ROW is rarely homogenous but typically comprises distinct community types or patches. Each patch may cover one to several square meters or more and is distinguished by differences in species composition and plant morphology (stem size and density). Patch types can range from low, grassy meadows to thickets of tall shrubs and trees. Patches likely also differ in their competitive ability and, of even greater significance, in their ability to reduce the establishment and growth of tree seedlings (Hill et al. 1995). Patches of vegetation may also differ in the herbivores that they attract and support. While more difficult to quantify, the effect of insect, bird, rodent, and deer populations on factors such as seed dispersal and seedling survival can be dramatic (Lawrence and Rediske 1962).

The encouragement of low-growing plant communities along ROWs in the Pacific Northwest has been limited and perhaps haphazard at best, and its overall effectiveness has not been examined quantitatively. In 1999, a program to develop stable, low-growing plant communities along highvoltage transmission ROWs was initiated in parts of western Oregon and Washington. Similar projects have continued in the eastern United States for over 30 years (Bramble et al. 1990), and monitoring on our sites could continue for years or decades to come. The initial part of the program was designed to address several issues:

- Which plant species dominate the ROW?

- Is there a pattern of plant communities (patch types) identifiable by species composition and morphology?

- If so, do any of these communities appear to be resistant to the establishment of Douglas-fir (Pseudotsuga menziesii) seedlings, a common hazard tree in the region? 
Other tree species of interest, alder (Alnus rubra) and bigleaf maple (Acer macrophyllum), did not occur frequently enough in our plots to allow a quantitative analysis.

\section{METHODS}

In 1999, three separate ROWs, approximately 5 ha each, were selected in the western foothills of the Cascade Mountains in Washington and Oregon (Figure 1). They represent only a subsample of the conditions in the region. Each ROW passes through a mountainous landscape covered by a dense, coniferous forest. The Willamette foothills site (WF) in Oregon had been used by the power utility since 1965. The Columbia River Gorge (CRG) and the Tacoma City Watershed (TCW) sites in Washington state had been used since 1938 and 1972, respectively. The vegetation along these rights-of-way had not been treated for at least 3 years before the beginning of the project. The CRG site was the lowest, at $100 \mathrm{~m}$ above sea level; TCW, the highest at $450 \mathrm{~m}$; and WF, intermediate, at $320 \mathrm{~m}$. The ROW was 80 to $100 \mathrm{~m}$ wide at WF and CRG and $160 \mathrm{~m}$ wide at TCW.

Vegetation sampling was done along a $2 \mathrm{~m}$ wide transect across the ROW from forest edge to forest edge. The first transect was placed at an arbitrary location, and subsequent transects were placed every 20 to $25 \mathrm{~m}$. Sampling plots $(2 \times$ $2 \mathrm{~m}$ ) were placed at the beginning of the transect and at $4 \mathrm{~m}$ intervals. In mid-spring, after budbreak but before full leaf expansion, we visually estimated the percentage of cover and measured the maximum height of each species of tree, shrub, and fern intercepting the plot. Total grass cover and total forb cover were recorded by group rather than by individual species. Conifer tree seedlings were counted if they were rooted within the sampling plot. Between 470 and 511 plots covering 0.2 ha, or $3 \%$ to $5 \%$ of the study area, were sampled at each site.

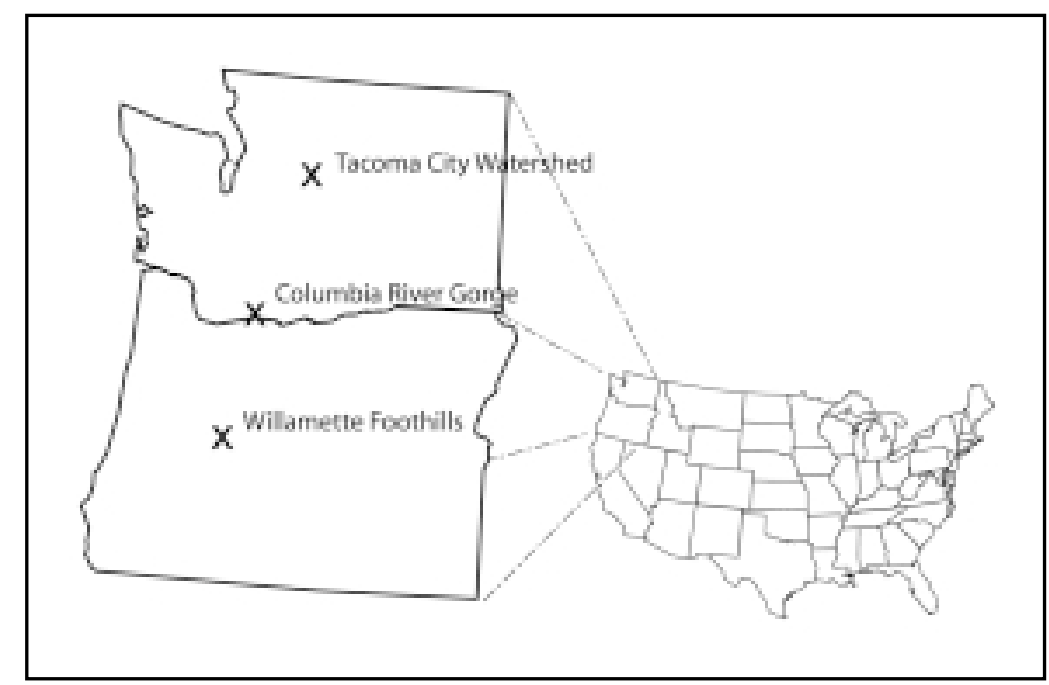

Figure 1. Schematic of the Pacific Northwest region; Xs indicate location of rights-of-way included in our survey.
Classifying sample plots based on their growth habit (physiognomy) and percentage of cover estimate involved three steps. First, species were assigned to one of several growth form types: forb, grass, fern, hardwood tree, tall shrub, and scotch broom (Cystisus scoparius, a non-native shrub), etc. Secondly, we used cluster analysis (McCune and Mefford 1999) to assign each plot to a community type based on the percentage of cover of each growth form (Table 1). The program grouped plots based on whether the plants were mainly herbaceous, native or exotic shrubs, trees, or tall shrubs. The analysis quickly and efficiently divided several hundred sample plots into six groups. A review of the original species cover estimates provided a check of the reliability of the cluster analysis groupings.

If all patch types were equally suitable for Douglas-fir, each patch type would have an equal density of Douglas-fir. The expected number of Douglas-fir seedlings within a community was proportional to the area occupied by that type (expected seedling number $=$ percentage of area $\times$ number of seedlings in all areas). We compared the observed and expected frequency of Douglas-fir occupying each community type using a goodness-of-fit test (G-test, Sokal and Rohlf 1995). If the number of seedlings observed was significantly less than expected, the patch type was deemed resistant to invasion by Douglas-fir. Because many of the Douglas-fir seedlings had survived previous cuttings, we ran the test using total seedling counts and again using only counts of previously uncut, and therefore the youngest, seedlings. The results were similar under both scenarios; hence, we report statistics only for the test using all seedling counts.

\section{RESULTS AND DISCUSSION}

The cluster analysis defined six different plant communities within our study sites, representing a gradient of woody plant cover and height (Table 1). Four of the community types were common to all sites. The relative amount of right-of-way covered by each community type was between $2 \%$ and $43 \%$ (Table 2). No single plant species or community dominated large contiguous areas of the ROW; rather, their distribution was very patchy. Much of this patchiness appeared to be related to environmental factors, such as slope position (ridge versus swale), aspect, and past disturbance, particularly road construction. For example, abandoned access roads were dominated by scotch broom at WF and CRG and red alder at TCW.

Douglas-fir seedlings were not randomly distributed among the various plant communities (Table 2). At TCW, three of the five communities present had fewer Douglas-fir than expected by chance. At CRG and WF, only two of the five communities had fewer Douglas-fir than predicted 
Table 1. Percentage of woody and herbaceous plant cover within six community types identified along electrical transmission rights-of-way in western Washington and Oregon. Values indicate the range of cover estimates recorded for each species in a given community type and a given study site.

\begin{tabular}{|c|c|c|c|c|}
\hline Community & Vegetation & TCW (\%) & CRG (\%) & WF (\%) \\
\hline \multicolumn{5}{|l|}{ Alder } \\
\hline Red alder & Alnus rubra & $10-80$ & - & - \\
\hline \multicolumn{5}{|l|}{ Broom } \\
\hline Scotch broom & Cystisus scoparius & - & $7-40$ & $12-80$ \\
\hline \multicolumn{5}{|l|}{ Herbs } \\
\hline Grasses & Poaceae & $8-35$ & $5-40$ & $5-65$ \\
\hline Forbs & Forbs, various & $1-6$ & $1-10$ & $1-10$ \\
\hline Bracken fern & Pteridium aquilinum & $2-10$ & $2-10$ & $1-5$ \\
\hline Thimbleberry & Rubus parviflorus & $5-20$ & - & - \\
\hline \multicolumn{5}{|l|}{ Herb/shrub } \\
\hline Grasses & Poaceae & $1-10$ & $2-7$ & $5-15$ \\
\hline Forbs & Forbs, various & $3-12$ & $3-10$ & $3-10$ \\
\hline Bracken fern & Pteridium aquilinum & $3-20$ & $2-10$ & $40-80$ \\
\hline Trailing blackberry & Rubus ursinus & $15-40$ & $2-8$ & $15-25$ \\
\hline Sword fern & Polystichum munitum & $2-10$ & $15-35$ & $40-55$ \\
\hline Snowberry & Symphoricarpus albus & - & - & $7-15$ \\
\hline Salal & Gaultheria shallon & $8-15$ & $5-15$ & $35-65$ \\
\hline Oregon grape & Berberis nervosa & $1-8$ & - & - \\
\hline Salmonberry & Rubus spectabilis & $1-11$ & - & - \\
\hline \multicolumn{5}{|l|}{ Shrub } \\
\hline Snowberry & Symphoricarpus albus & - & $15-60$ & $7-85$ \\
\hline Thimbleberry & Rubus parviflorus & $15-30$ & $12-50$ & $15-35$ \\
\hline Salal & Gaultheria shallon & $15-95$ & $15-45$ & $35-65$ \\
\hline Oregon grape & Berberis nervosa & $10-40$ & - & - \\
\hline Salmonberry & Rubus spectablilis & $10-50$ & - & - \\
\hline \multicolumn{5}{|l|}{ Tree and tall shrub } \\
\hline Hazel & Corylus cornuta & - & $11-70$ & $20-100$ \\
\hline Vine maple & Acer circinatum & $15-80$ & $25-96$ & $50-75$ \\
\hline Cascara & Rhamnus purshiana & - & $15-45$ & $20-60$ \\
\hline Bigleaf maple & Acer macrophyllum & 一 & $15-35$ & - \\
\hline
\end{tabular}

$\mathrm{TCW}=$ Tacoma City Watershed; CRG = Columbia River Gorge; WF = Willamette foothills. community. Fifty woody plant species were recorded for the three sites combined. At least 17 of these were common to all sites, and an additional 15 were common to at least two sites. Four of the 17 species common to all sites-salal (Gaultheria shallon), thimbleberry (Rubus parviflorus), bracken fern (Pteridium aquilinum), and sword fern (Polystichum munitum) — were likely candidates for low-growing plants capable of inhibiting tree regeneration (Haeussler et al. 1990). Three more species-snowberry (Symphoricarpos albus), Oregongrape (Berberis nervosa), and salmonberry (Rubus spectabilis) were abundant on at least one site and exhibit a low-growth form capable of forming dense cover under favorable conditions.

Although forbs and grasses were common throughout the ROWs, under a dominant cover of woody plants, herbaceous cover was typically less than $1 \%$. Grasses reached higher cover values (>20\%) along access roads and within a meadow at the base of a steep slope at TCW and in patches at CRG and WF. Forb-dominated patches were not frequent enough to determine if they would effectively impede tree establishment.

An obvious similarity between many of the common plants within the ROWs is the vegetative growth
(Table 2). Given the density of mature Douglas-fir trees bordering all three ROWs, the seed rain onto the various community types is likely frequent and abundant. Since the proportion of Douglas-fir seedlings was not evenly distributed among the different patch types, it is reasonable to conclude that some patch types were more resistant to seedling establishment than others. Consistently across the three ROWs, the tree/tall shrub community contained fewer Douglas-fir seedlings than expected and was considered the most resistant to seedling establishment. For at least two of the three sites, the shrub and the herbaceous communities appeared to be resistant to Douglas-fir as well (Table 2).

Resistance to seedling invasion is conferred, in part, by the growth habit of the individual species making up the capability. Several shrub species occupying our sites can form dense layers of roots [e.g., vine maple (Acer circinatum), beaked hazelnut (Corylus cornuta var. californica), salal, and salmonberry]. Their belowground shoots also have numerous buds. Where disturbance, including ROW maintenance, removes the aboveground material, these species can respond with a rapid flush of growth (Haeussler et al. 1990). These characteristics make them suitable candidates for lowgrowing plant communities capable of filling in the gaps left after the removal of unwanted vegetation. Some grassdominated patches also appeared resistant to tree seedling establishment. Future work will include identifying which grass species are present and which might be most resistant to tree invasion. 
Douglas-fir seedlings were 0.5 to $3 \mathrm{~m}$ tall (average 1.4 $\mathrm{m})$. The density of Douglas-fir seedlings ranged from several hundred to more than 1,500 stems/ha (Table 3). Many seedlings had already been cut down with a chain saw and regrew from an uncut lateral branch (Table 3). Cutting occurred during the last maintenance cycle, 3 or more years before our survey. More careful removal of the treetop and all lateral branches would achieve a lower density of conifer seedlings and perhaps a longer interval between successive treatments. Certainly, less effort would be required each maintenance cycle to remove Douglas-fir trees.

Table 2. The percentage of area within each community type and the percentage of sample plots without Douglas-fir seedlings for each community type for three study sites in Washington and Oregon, 2000. Community types appear in order of most resistant to least resistant to Douglas-fir seedling establishment. A separate likelihood ratio chi-square test analysis is reported for each site.

\begin{tabular}{clc}
\hline Study area (\%) & Community type & Plots without Douglas-fir $(\%)$ \\
\hline TCW & & $100^{*}$ \\
9 & Herb & $98^{*}$ \\
9 & Tree/tall shrub & $89^{*}$ \\
43 & Shrub & 74 \\
24 & Herb/shrub & 69 \\
15 & Alder & (Chi-square $=44.3 ; \mathrm{DF}=4 ; N=463 ; P<0.0001)$
\end{tabular}

\section{CRG
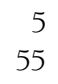 \\ 4 \\ 9 \\ 26}

Herb
Tree/tall shrub
Broom
Herb/shrub
Shrub

(⿸丆口 $=44.3 ; \mathrm{DF}=4 ; \mathrm{N}=463 ; \mathrm{P}<0.0001)$

.

WF
12
18
24
2
42

Tree/tall shrub
Shrub
Broom
Herb
Herb/shrub

$82^{*}$

$77^{*}$

61

60

49

(Chi-square $+32.8 ; \mathrm{DF}=4 ; N=452 ; P<0.0001)$

"Observed number of plots without Douglas-fir more than expected by random chance. growing plant criteria.

\section{SUMMARY AND CONCLUSIONS}

Several patch types in our study areas were composed of low-growing plants. We observed examples of both woody and nonwoody communities, which in some settings were resistant to Douglas-fir establishment but in other settings ancared trees but obviously this type does not conform to our low-

We calculated the density of Douglas-fir seedlings occupying rights-of-way several years after the most recent vegetation control and maintenance cycle. Thus, the data from one survey represent the combined results of several growing seasons and an overall measure of the resistance of each community type to Douglas-fir. Of particular interest regarding stable, lowgrowing plant communities were the number of turfforming grasses and clonally reproducing shrubs. Moderate to high cover of these species was correlated with low levels of conifer seedling establishment. Further investigation of the character of these communities, how they are encouraged, and how they affect tree seedling establishment and growth is warranted. In general, management practices that maintain or expand their presence on the ROWs have a great potential to reduce maintenance (Hill et al. 1995). The ROW vegetation described in this study and its relationship to seedling establishment will be used to develop further questions and to inform future research, including experimental manipulations.

Table 3. Mean density (s.e.) of Douglas-fir seedlings along three rights-of-way surveyed in the Pacific Northwest, 2000.

\begin{tabular}{lll}
\hline Site & $\begin{array}{l}\text { Density } \\
\text { (seedlings/ha) }\end{array}$ & $\begin{array}{l}\text { Regrowth } \\
\text { after cutting (\%)* }\end{array}$ \\
\hline TCW & $735(7.2)$ & $2(0.8)$ \\
CRG & $526(8.0)$ & $15(1.1)$ \\
WF & $1586(10.8)$ & $34(0.9)$ \\
\hline
\end{tabular}

"Proportion of seedlings or saplings that had regrown from an uncut lateral branch after having been cut down.

\section{LITERATURE CITED}

Bonneville Power Administration. 2000. Transmission System Vegetation Management Program Final Environmental Impact Statement. Technical Report DOE/EIS-0285, U.S. Department of Energy, Washington, DC. 157 pp. Bramble, W.C., W.R. Byrnes, and R.J. Hutnik. 1990. Resistance of plant cover types to tree seedling invasion on an electric transmission right-of-way. J. Arboric. 16(5):130-135. 
Bramble, W.C., R.H. Yahner, W.R. Byrnes, and S.A. Liscinsky. 1992. Small mammals in plant cover types on an electric transmission right-of-way. J. Arboric. 18(6):316-321.

Haeussler, S., D. Coates, and J. Mather. 1990. Autecology of Common Plants in British Columbia: A Literature Review. British Columbia Economic \& Regional Development Agreement, Victoria, BC. 272 pp.

Hill, J.D., C.D. Canham, and D.M. Wood. 1995. Patterns and causes of resistance to tree invasion in rights-of-way. Ecol. Appl. (5) :459-470.

Lawrence, W.H., and J.H. Rediske. 1962. Fate of sown Douglas-fir seed. For. Sci. 8(3):210-218.

McCune, B., and M.J. Mefford 1999. Version 4.2. PC-ORD Multivariate Analysis of Ecological Data. MjM Software Design, Gleneden Beach, OR.

Sokal, R.R., and FJ. Rohlf. 1995 Biometry: The Principles and Practice of Statistics in Biological Research (3rd ed.). W.H. Freeman and Co, New York, NY. 887 pp.

Acknowledgments. This project is a joint effort between Oregon State University, Bonneville Power Administration, and Western Environmental Consultants, Inc. We gratefully acknowledge the funding provided by the Bonneville Power Administration. We thank A. Roorbach for assistance in the field component of this project and two anonymous reviewers for their comments on an earlier draft of the manuscript. This is paper 3539 of the Forest Research Laboratory, Oregon State University.

*Department of Forest Science

Oregon State University

Corvallis, OR 97331, U.S.

*Corresponding author: Jeff Shatford (Jeff.Shatford@orst.edu)

Résumé. Un programme pour évaluer l'utilité de peuplements composés de plantes à faible développement qui défavorisent l'implantation de peuplements de conifères à partir de semis le long des emprises de lignes électriques de transport a été initié en Oregon et au Washington en 1999. Trois sites ont été décrits au moyen d'un pourcentage de recouvrement de toutes les espèces arborées et de la densité en tiges d'arbres, et ce en échantillonnant 1376 parcelles de $2 \times 2 \mathrm{~m}$. Nous nous sommes demandés si les semis d'arbres, principalement le sapin de Douglas (Pseudotsuga menziesii), étaient distribuées aléatoirement au sein des types de peuplements définis en fonction de la hauteur du développement et du pourcentage de recouvrement. Les semis de sapins de Douglas n'étaient pas distribués aléatoirement et ils étaient moins présents dans les peuplements déjà composés d'une végétation dense. Ceci incluait certains, mais pas tous, les peuplements composés d'espèces à faible déploiement, par exemple les zones denses en graminées ou les peuplements arbustifs de faible à fort recouvrement. Les semis de sapins de Douglas étaient peu fréquents à l'intérieur des zones dominées par les arbres et les grands arbustes; par contre cela ne répondait pas aux besoins du programme en espèces à faible déploiement. Une des préoccupations particulières pour les gestionnaires de végétation était le grand nombre de semis de sapins de Douglas qui se formaient à partir des repousses d'une section latérale non coupée.

Zusammenfassung. 1999 wurde in Washington und Oregon ein Programm initiiert, welches die Nützlichkeit von langsamwachsenden Pflanzengesellschaften bei der Kontrolle von aufkeimenden Koniferensämlingen in Stromkorridoren untersuchen soll. Es wurden von 1376 Flächen von $2 \mathrm{~m}$ x 2 m Proben entnommen, um den Prozentsatz des Bewuchses durch mehrjährige Pflanzen und deren Stammdichte zu messen. Wir fragten uns, ob Sämlinge, (Douglasie) eher zufällig in den Gesellschaftstypen, die durch Wachstumsform und Bedeckungsgrad definiert sind, verteilt waren. Douglasiensämlinge waren nicht zufällig verteilt und tauchten in bereits bestehenden dichten Vegetationsgruppen weniger auf. Das beinhaltet auch einige, aber nicht alle, kleinwachsenden Gemeinschaften, z.B. Flächen mit dichtem Gras oder Strauchgesellschaften mttlerer und hoher Größe. Douglasiensämlinge waren weniger häufig in Flächen mit hohem Baum- und Strauchbestand, aber das passt nicht zur Fragestellung des Programms. Von besonderem Interesse für Vegetationsmanager war die große Anzahl von Sämlingen, die aus ungeschnittenen lateralen Seitentrieben wachsen.

Resumen. En Washington y Oregon, en 1999, se inició un programa para determinar la utilidad de establecer comunidades de plantas de lento crecimiento a lo largo del derecho de vía. Se describió el por ciento de cobertura de todas las especies maderables y la densidad basal en 1376 parcelas de tres sitios de muestreo, cada una de $2 \mathrm{~m} \times 2 \mathrm{~m}$. Se averiguó si los brinzales de los árboles, principalmente abeto-Douglas (Pseudotsuga menziesii), estaban distribuidos al azar entre los tipos de comunidades definidas por forma de crecimiento y cobertura. Los brinzales de abeto-Douglas no estaban distribuidos al azar y se presentaban con menos frecuencia en las comunidades ocupadas con vegetación densa. Esto incluyó algunas, pero no todas, comunidades de lento crecimiento-por ejemplo, áreas de pasto denso o comunidades de arbustos de moderada a alta cobertura. Los brinzales de abeto-Douglas fueron poco frecuentes dentro de rodales dominados por árboles y arbustos altos, pero esto no cumplió con los requerimientos de lento crecimiento del programa. De particular preocupación para los manejadores del programa fue el gran número de brinzales de abetoDouglas que rebrotaron en una rama lateral. 